\title{
Ecological relationships between poisonous plants and rangeland condition: A Review
}

\author{
MICHAEL H. RALPHS
}

Author is Rangeland Scientist, USDA/ARS Poisonous Plant Lab, Logan Utah 84341.

\begin{abstract}
In the past, excessive numbers of livestock on western U.S. rangelands, reoccurring droughts, and lack of management resulted in retrogression of plant communities. Poisonous plants and other less palatable species increased with declining range condition and livestock were forced to eat these poisonous species because of a shortage of desirable forage, resulting in large, catastrophic losses. The level of management on most western rangelands has improved during the last 60 years, resulting in marked improvement in range condition; yet losses to poisonous plants still occur, though not as large and catastrophic as in the past. Some poisonous species are major components of the pristine, pre-European plant communities [tall larkspur (Delphinium barbeyi Huth), Veratrum californicum Durand, water hemlock (Cicuta douglasii (DC.)Coult. \& Rose), bracken fern (Pteridium aquilinum (L.) Kuhn), chokecherry (Prunus virginiana L.), Ponderosa pine (Pinus ponderosa Lawson), and various oak species (Quercus spp.)]. Although populations of many poisonous seral increaser species have declined with better management, they are still components of plant communities and fluctuate with changing precipitation patterns [locoweed (Astragalus and Oxytropis spp.), lupine (Lupinus spp.), death camas (Zigadenus spp.), snakeweed (Gutierrezia spp.), threadleaf groundsel (Senecio longolobis Benth.), low larkspur (Delphinium nuttallianum Pritz.), timber milkvetch (Astragalus miser Dougl. ex Hook.), redstem peavine (A. emoryanus (Rydb.) Cory), western bitterweed (Hymenoxys odorata D.C.), orange sneezeweed (Helenium hoopesii Gray), twin leaf senna (Cassia roemeriana Schelle), and white snakeroot (Eupatorium rugosum Houtt)]. Many of the alien invader species are poisonous: [Halogeton glomeratus (Bieb.) C.A. Mey, St. Johnswort (Hypericum perforatum L.), poison hemlock (Conium maculatum L.), tansy ragwort (Senecio jacobaea L.), hounds tongue (Cynoglossum officinale L.), leafy spurge (Euphorbia esula L.), yellow star thistle (Centaurea solstitialis L.) and other knapweeds (Centaurea spp.)]. Poisoning occurs when livestock consume these plants because they are either relatively more palatable than the associated forage, or from management mistakes of running short of desirable forage.
\end{abstract}

Key Words: Poisonous plants, rangeland condition, larkspur, Delphinium spp., locoweed, Astragalus spp., Oxytropis spp., lupine, Lupinus spp., death camas, Zigadenus spp.

Manuscript 27 May 00

\section{Resumen}

En el pasado, el número excesivo de ganado en los pastizales del oeste de los Estados Unidos, las sequías recurrentes y la falta de manejo resultaron en la retrogresión de las comunidades vegetales. Las plantas tóxicas y otras especies menos gustadas se incrementaron declinando la condición del pastizal y el ganado fue forzado a comer estas especies tóxicas debido a la escases de forraje deseable, resultando en perdidas grandes y catastróficas. Durante los últimos 60 años, el nivel de manejo de la mayoría de los pastizales del oeste ha mejorado resultando en una marcada mejoría de la condición del pastizal; pero las perdidas por plantas tóxicas todavía ocurren, aunque no son tan grandes ni catastróficas como en el pasado. Algunas especies tóxicas son componentes principales de las comunidades vegetales prístinas preeuropeas ["Tall larkspur" (Delphinium barbeyi Huth), Veratrum californicum Durand, "Water hemlock" (Cicuta douglasii (DC.)Coult.. \& Rose), "Bracken fern" (Pteridium aquilinum (L.) Kuhn), "Chokecherry" (Prunus virginiana L.), "Ponderosa pine" (Pinus ponderosa Lawson) y varias especies de encino (Quercus spp.)]. Aunque las poblaciones de muchas de estas especies tóxicas incresoras han disminuido con un mejor manejo, ellas todavía son componentes de las comunidades vegetales y fluctúan con los patrones cambiantes de precipitación ["Locoweed" (Astragalus and Oxytropis spp.), "Lupine" (Lupinus spp.), "Death camas" (Zigadenus spp.), "Snakeweed" (Gutierrezia spp.), "Threadleaf groundsel" (Senecio longolobis Benth.), "Low larkspur" (Delphinium nuttallianum Pritz.), "Timber milkvetch" (Astragalus miser Dougl. ex Hook.), "Redstem peavine" (A. emoryanus (Rydb.) Cory), "Western bitterweed" (Hymenoxys odorata D.C.), "Orange sneezeweed" (Helenium hoopesii Gray), "Twin leaf senna" (Cassia roemeriana Schelle) y "White snakeroot" (Eupatorium rugosum Houtt)]. Muchas de las especies invasoras extranjeras son tóxicas: [Halogeton glomeratus (Bieb.) C.A. Mey, "St. Johnswort"' (Hypericum perforatum L.)," Poison hemlock" (Conium maculatum L.), "Tansy ragwort" (Senecio jacobaea L.), "Hounds tongue" (Cynoglossum officinale L.), "Leafy spurge" (Euphorbia esula L.), "Yellow star thistle", (Centaurea solstitialis L.) y otras "Knapweeds" (Centaurea spp.)]. EI envenenamiento ocurre cuando el ganado consume estas plantas porque ellas son de una gustocidad relativamente mayor que el forraje asociado o por errores de manejo durante escases de forraje deseable.

Poisoning Related to Overgrazing in the Past

Two factors contributed to the high incidence of poisonous plant problems on western U.S. rangelands: abundance of toxic plants, both in number of species and density of plants; and overgrazing. Western rangelands are extremely variable in topogra- 
Table 1. Poisonous plants found in physiographic regions and plant communities.

\begin{tabular}{lll}
\hline \hline & Great Plains and Prairies & \\
\hline Tall-grass prairie & Short/Mid-grass prairie & Oak/mesquite savanna \\
\hline White snakeroot & Plains larkspur & Bitterweed \\
Riddells groundsel & Locoweed & Twin leaf senna \\
& Threadleaf groundsel & Oak \\
& Broom snakeweed & \\
& Redstem peavine & \\
\hline
\end{tabular}

\begin{tabular}{lll}
\hline & Southwest Deserts & \\
\hline Sonoran Desert & Desert grasslands & Mohave Desert \\
\hline Garboncillo & Sacahuista & Desert baileya \\
Mescal bean & Rayless goldenrod & Milkweed \\
Red-stem peavine & Broom snakeweed & Coyotillo \\
Wooly paperflower & &
\end{tabular}

Mountains

\begin{tabular}{lll}
\hline Mountain brush & Mt. big sagebrush & Aspen / conifer \\
\hline Orange sneezeweed & Death camas & Tall larkspur \\
Chokecherry & Low larkspur & Timber milkvetch \\
Oak & Lupine & False hellebore \\
& & Ponderosa pine \\
\hline
\end{tabular}

\begin{tabular}{lll}
\hline & Colorado Plateau / Great Basin & \\
\hline Salt desert shrub & Sagebrush steppe & Juniper / Pinyon \\
\hline Halogeton & Death camas & Locoweed \\
Greasewood & Anderson larkspur & Lupine \\
Horsebrush & Water hemlock & Pingue \\
\hline
\end{tabular}

phy, soils, and climate, resulting in very diverse plant communities. Many of the plant species contain toxins, and if eaten in sufficient quantity, would poison animals. Kingsbury (1964) described over 1,000 poisonous plants, found mostly in the western US and Canada.

Livestock poisoning became a significant problem as settlers moved west and their livestock encountered a vast array of poisonous plants (Table 1). The plains and prairies were fully stocked by the 1880 's, and the mountains and deserts by the turn of the century. The number of livestock on western rangelands exceeded the biological carrying capacity and management was generally lacking. Retrogression of the plant communities following misuse and reoccurring drought contributed to livestock poisoning. Poisonous and other less palatable species increased as the more desirable forage plants were heavily grazed and died out, and animals were forced, through shortage of other forage, to eat the poisonous species.

The problem was sufficiently severe that it became a national concern. The USDA Bureau of Plant Industry commissioned a team of scientists to study the problem beginning with V.K. Chestnut in 1894 and C.D. Marsh in 1905. Marsh (1913) published a short bulletin Stock poisoning Due to Scarcity of Food in which he listed the conditions where livestock were poisoned by major plants of that day:

1. The loco habit is usually acquired during a season of short feed, when the locoweeds (Astragalus and Oxytropis spp.) are the most attractive form of vegetation.

2. Larkspur (Delphinium spp.) poisoning is most likely to occur either during the season of short feed, or on overgrazed areas; in either case the larkspur is the most conspicuous form of vegetation to attract the animals and is eaten in lieu of anything better.

3. The roots of water hemlock (Cicuta douglasii (DC.)Coult.. \& Rose) are picked up when there is little else to eat and with disastrous results.

4. Successive bands of sheep are driven over the same trail until everything suitable for food disappears, and then there follow cases of poisoning from wild cherry [chokecherry (Prunus virginiana L.)]. On some trails there is an almost continuous hedge of wild cherry, and the leaves are eaten as high as the sheep can reach.

5. Sheep are sometimes bedded in the same place for several successive days. Under such circumstances everything near the bed ground is eaten, and if there are any poisonous plants some of the sheep are pretty sure to get them.

Large catastrophic livestock losses occurred because there were too many livestock on the ranges, management was almost nil, and knowledge of poisonous plants was meager.

Rangelands today are in the best condition that they have been in for the last 100 years (Box and Malechek 1987), due to improved and intensified range and livestock management. Knowledge of poisonous plants, their toxins and conditions of poisoning has increased. Thus, the incidence of large, catastrophic losses has declined. The following is a chronological list of statements taken from the poisonous plant literature and prominent range management text books illustrating the evolution of the relationship between range condition and livestock poisoning:

Marsh (1913) - "Stock seldom eat poisonous plants by choice, but only when induced or compelled by the scarcity of other food or on overgrazed ranges."

Stoddart and Smith (1943)"Poisonous plants cause great loss on western ranges. Losses are increasing in spite of increased knowledge concerning poisonous plants and treatment of poisoned animals."

Stoddart et al. (1949) "Poisoning is natures' sign of a sick range."

Stoddart and Smith (1955) - "Losses have decreased measurably because stockmen have learned to recognize poisonous species and have learned to avoid them or to minimize damage from them."

Stoddart et al. ( 1975) - "Poisonous plants are normal components of range ecosystems. Most losses can be avoided by good management; others occur with such irregularity due to unpredictable conditions that they constitute an ever-present hazard."

Vallentine (1990) - "Prolonged droughts and overgrazing sometimes force livestock to eat harmful amounts of poisonous plants. On good condition ranges, poisonous plants are subjected to intense competition from vigorous, high producing forage plants, and there is a great variety of plant species available for selective grazing."

Schuster (1978) stated that good range management is the surest and most economical means of reducing livestock loss to poisonous plants. Desirable forage 
Table 2. Plant/animal/environment interactions of poisoning

\begin{tabular}{lll}
\hline \hline Plant & Animal & Environmental \\
\hline Ecology & Species and class & Plant population cycle \\
Habitat & Physiological condition & Toxin level \\
Abundance & Hunger & Animal behavior \\
Toxin & Preference & Relative palatability \\
\hline
\end{tabular}

species are encouraged, while undesirable and poisonous species are suppressed, and animals are provided abundant nutritious forage.

\section{Plant/Animal/Environment Interactions of Poisoning}

In spite of the improved range conditions, losses to poisonous plants continue to occur, although not at the catastrophic levels of the past. Dwyer (1978) stated "We are long past the time we can pass off poisonous plants as a symptom of an overgrazed range." Dwyer called attention to the need for research on plant/animal interactions of poisoning (Table 2). I would add to that, the environmental factors that influence both plants and animals. We need to consider individual plant species, their toxin and concentration within the plant; the plants' ecological status (Table 3 ), the soils and sites they occupy, their population cycles, and other factors that influence their relative abundance.

The animal factors depend first on whether the animal eats the toxic plant. Many plants are highly toxic, but seldom eaten [i.e. water hemlock, (Cicuta douglasii (DC.)Coult.. \& Rose) narrow leaved milkweeds (Asclepias spp), jimson weed (Datura stramonium L.)]. If the animal eats the plant, poisoning depends on the toxin level in the plant, and the rate of consumption. The rate of consumption depends on the plants relative palatability and its abundance in the plant community. Palatability of any plant is relative to what other forage is available. Some poisonous plants are relatively more palatable than the associated vegetation, i.e. larkspur (Delphinium spp.) and locoweeds (Astragalus spp.), whereas the lack of better alternatives and hunger may drive animals to consume other poisonous plants. Some situations may cause animals to graze non-selectively, such as releasing hungry animals into areas of poisonous plants, or introducing non-native animals to areas of unfamiliar poisonous plants.

Environmental factors affect both plants and animals. Population cycles occur for alkaloids, which cause muscular paralysis many poisonous plants, with die-offs occurring during drought and population explosions during wet periods. Weather stress (drought, temperature, frost) can increase toxin concentration in many plants. Specific weather events can also affect grazing behavior, causing animals to increase consumption of specific poisonous plants. All of these factors interact to determine whether an animal is poisoned.

\section{Ecological Status of Important Poisonous Plants}

\section{Larkspurs}

Larkspurs kill more cattle on mountain and foothill rangelands than any other plant or disease. Early losses ranged from $3-5 \%$ of cattle grazing on larkspur infested rangelands, with over 5500 cattle deaths reported annually (Aldous 1917). We estimated over 1,000 cattle die annually from larkspur in the Intermountain Forest Service Region (Nielsen and Ralphs 1988). Losses of similar magnitude occur in the Rocky Mountain and Northern Forest Service Regions, and additional losses occur on private rangelands. Larkspurs contain norditerpenoid and rapid death from respiratory failure. Sheep are more resistant to larkspur alkaloids than are cattle (Olsen 1978).

The tall larkspur complex is comprised of 4 species: tall larkspur (D. barbeyi Huth.) in southcentral Wyoming,

Table 3. Ecological status of important poisonous plants.

\begin{tabular}{lll}
\hline \hline Pristine species & Seral & Alien \\
Pre-European & Increaser species & Invader species \\
\hline Tall larkspur & Locoweed & Halogeton \\
Western false hellebore & Lupine & St. Johns wort \\
Water hemlock & Death camas & Poison hemlock \\
Bracken fern & Snakeweed & Tansy ragwort \\
Chokecherry & Threadleaf groundsel & Houndstongue \\
Ponderosa pine & Low larkspur & African rue \\
Oak spp. & Timber milkvetch & Leafy spurge \\
& Bitterweed & Yellow star thistle \\
& Twin leaf senna & Knapweeds \\
& White snakeroot & \\
\hline
\end{tabular}

Colorado and southern Utah; duncecap larkspur (D. occidentale Wats.) in north and western Wyoming, Montana, Idaho, northern Utah and Nevada; Sierra larkspur (D. glaucum Wats.) in California and Oregon and northward to Alaska; and waxy larkspur (D. glaucescens $\mathrm{Rydb}$ ) in southwest Montana and central Idaho. These species differ in toxicity (Ralphs et al. 1997), but inhabit similar ecological sites.

Ellison (1954) conducted one of the most comprehensive ecological studies of the subalpine vegetation of the Wasatch Plateau in central Utah. Tall larkspur occurred in 2 plant communities. It was a principal component of the mixed upland herb association in its climax stage, comprising $2-5 \%$ of total cover, ranging up to $50 \%$ in some areas. Tall larkspur was also one of the most conspicuous species of the tall forb community on snow drift sites and at the edge of wet meadows and along streams. Abusive grazing from 1880 to 1905 practically destroyed the original herbaceous vegetation, resulting in accelerated erosion and destructive flooding in the valleys below. Tall larkspur was one of the most tenacious forbs in the original complex, persisting on elevated hummocks held together by its extensive root system. Forest Service management and reduction in livestock from 1910 to 1950 arrested the deterioration, which allowed secondary succession to proceed. Range surveys in 1912, 1936, and 1946 documented improvement in vegetation composition. Ellison compared ungrazed relic areas to ranges grazed by either sheep or cattle. Tall larkspur declined on sheep range, indicating that sheep grazing reduced its density. Thus on sheep ranges, it acts as a decreaser species. On ranges grazed by cattle, its density did not change. It is doubtful that further reduction in live- 
stock grazing, or removal of grazing would decrease larkspur populations.

Sierra larkspur is described as an increaser species in the transition from the fescue prairie to forest in western Canada (Looman 1984). Overgrazing of range and open forests in this area led to an increase in its density, and significant cattle poisoning. With continued heavy grazing, it can be grazed out of the fescue grasslands. In the northern boreal forests and in the tops of the Sierra and Cascade mountains, it occurs along stream banks and willow thickets as a minor component of the climax community.

The low larkspur species form a complex group which introgress into each other. D. menziesii DC. was first to be implicated with poisoning of sheep in Montana (Wilcox 1897). D. bicolor Nutt. of the northwest was studied thoroughly in early toxicity studies (Chesnut and Wilcox 1901). D. nelsonii Greene occurs throughout Utah and Colorado. Presently, D. nuttalanium Pritz. which extends northward into Canada, now encompass all of these species, except for D. bicolor. All of these species or varieties are considered increaser plants; increasing in density as grazing pressure increases and range condition deteriorates. Thus, improvement in range condition is likely to reduce their density.

The low larkspurs grow early in the spring, flower in May and June, then senesce. They are toxic throughout their growing period but only cause poisoning problems when they grow in dense patches. Normally, they are scattered, but in cool wet springs when grasses are slow to develop, they increase, or are more apparent, thus causing poisoning. Since they dry up in early summer, the management recommendation is to wait until low larkspur matures and other forages are abundant before turning cattle in (Pfister and Gardner 1999).

Plains larkspur (D. geyerii Greene) causes most of the poisoning problems in Wyoming and eastern Colorado (Alley and Lee 1970). It is favored by cool, wet springs, when most poisoning occurs before grasses start rapid growth. Anderson larkspur (D. andersonii Gray) generally grows as isolated plants on foothill ranges throughout the Intermountain region. It only causes problems when it grows in dense patches on overgrazed ranges where little other forage is available (Fleming et al. 1923).

\section{Locoweeds}

Marsh(1909) stated, "The so-called 'locoweed disease' has been a source of most serious complaint for many years, especially from stockmen on the Great Plains east of the Rocky Mountains. While the losses have varied in severity, they have reached such a magnitude as to make the matter of national concern." Marsh surveyed the government files and existing literature and found that locoweed poisoning was often confused with starvation. Marsh's early opinion was "An abundance of good feed would greatly reduce and perhaps eliminate the problem."

White locoweed, or white pointloco (Oxytropis sericea Nutt. ex Torr. \& Gray), is the most wide-spread locoweed species, ranging on the eastern foothills of the Rocky mountains from Canada to New Mexico, and on mountain tops in the Colorado Plateau and Great Basin. Payne (1957) conducted a study of its' ecology and life history and concluded that white locoweed was found on dry sites, such as rocky ridges and gravely plains. His research found the overriding soil factor influencing the presence of white locoweed was the presence of coarse rock fragments. Soils with greater than $15 \%$ of coarse fragments by volume, or very shallow soils with fractured rock beneath favored white locoweed. Soil texture was not definitive, since all soils where it occurred were varieties of loam. He concluded that the coarse rocks allowed for deep percolation of water, which can be accessed by the deep tap root of white locoweed, thus allowing it to survive in droughty sites. Ralphs and Cronin (1987) also found that white locoweed preferred shallow rocky soils in north western Utah, where it exhibits a stress tolerant survival strategy.

Payne's (1957) second objective was to determine the influence of grazing on the abundance of white locoweed. He described 8 fence line contrasts encompassing the same soils, but differing range condition. Basal density index of white locoweed increased as range condition deteriorated from excellent to good condition, but decreased when condition further declined from good to fair. He concluded that white locoweed was a typical increaser species, and was positively correlated with other increaser grasses and forbs, such as prairie junegrass, western wheatgrass, blue grama, needleleaf sedge, fringed sagewort, and phlox.

In germination trials, Payne (1957) reported white locoweed had a higher germination rate on bare soils. He reasoned that bare soils would provide greater scarification from soil particles for the hard seed coat, and that higher soil temperatures would enhance germination. He concluded that range deterioration caused by heavy grazing is a factor in the increase of white locoweed populations.

Weather also influences locoweed populations. Although white locoweed appears to be more persistent and longer-lived than Astragalus locoweeds, its populations still cycle. Marsh (1909) observed the white locoweed was particularly abundant in wet years, but nearly disappeared in dry seasons. We found that white locoweed populations in northeast New Mexico and north central Colorado died out in the respective droughts in 1996 and 1997 (Ralphs, unpublished data).

Many of the semi-desert Astragalus locoweeds experience extreme population cycles and exhibit opportunistic survival strategies that are independent of grazing pressures. They germinate following autumn rains, remain green over winter, flower in spring, and may continue to grow for 1 or 2 years until the next drought occurs, and the population dies back (Welsh 1989). Barnes (1913) related that the spring of 1888 was a particularly bad loco (probably A. lentiginosus Dougl.) season in northern Arizona, and that thousands of locoed horses and cattle died. The previous winter was unusually wet, followed by heavy rains in the early spring. Population outbreaks of $A$. lentiginosus var. wahweapensis Welsh occurred every 6 to 8 years in the Henry Mountain area of southeast Utah (Ralphs and Bagley 1988) and were strongly correlated with aboveaverage fall and spring precipitation. Population outbreaks of $A$. pubentissimus T. \& G. occurred in eastern Utah in 1918, 1957, 1965 (James et al. 1968), and in 1996 (Ralphs, unpublished data), causing catastrophic livestock loss, yet the plants were practically nonexistent in other years. Standing crop of woolly locoweed (A. mollissimus Torr.) averaged $190 \mathrm{~kg} / \mathrm{ha}$ in a grazing trial at Gladstone NM in 1991 (Ralphs et al. 1993), but totally died out 2 years later.

In summary, most locoweeds are increaser species; increasing as range condition declines. Therefore, improving range condition should reduce their density, though will probably not eliminate the problem. Populations of both Oxytropis and Astragalus locoweeds cycle with 
weather. They tend to increase during wet years, and die out during drought.

\section{Milkvetch Species Containing Nitrotoxins}

About half of the Astragalus species in North America contain nitrotoxins. Unlike the locoweeds, nitrotoxins cause acute poisoning in the form of respiratory failure, and more long-term weakness in the hind legs from demylenization of the spinal cord.

Timber milkvetch (A. miser Dougl. ex Hook) is an important poisonous plant of the upper rough fescue grasslands and lower montain areas of British Columbia and Alberta Canada. It also occurs in open areas of woodlands and within the mountain big sagebrush communities southward throughout the Rocky Mountains. MacDonald (1952) stated that overgrazing was undoubtedly the greatest single factor contributing to timber milkvetch poisoning. It is unpalatable when adequate forage is available, but upon depletion of desirable forage, stock will consume large quantities. Later grazing studies verified that cattle avoided eating timber milkvetch when adequate grass was available, but consumed increasing quantities as grass became scarce (Quinton et al. 1989). However in timbered areas, milkvetch was relatively more palatable than pinegrass (Majak et al. 1996). Timber milkvetch poisoning remains a significant poisoning problem in southern Canada even though range conditions have improved.

Red-stem peavine (A. emoryanus (Rybd.) Cory) is a winter annual on shortgrass prairies of southern New Mexico and west Texas. In dry years, plants are small and scattered. When precipitation is timely and abundant, seeds germinate and plants grow profusely, often forming a veritable carpet on large areas of rangeland. A population outbreak occurred in the winter of 1974 and spring of 1975 in the region surrounding Roswell New Mexico. Cattle mortality averaged $2-3 \%$, and morbidity averaged 15-20\% (Williams et al.1979)

\section{Lupine}

Lupines (Lupinus spp.) are among the most conspicuous of the flowering plants on foothill and mountain rangelands, with over 100 species in the western US and Canada. Because of hybridization, their taxonomy is difficult. There are 2 toxic syndromes caused by Lupines. Quinolizidine alkaloids cause acute respiratory failure, primarily in sheep. The following species have been responsible for the majority of sheep losses: L. leucophyllus Dougl. ex Lindl., L. leucopsis Agardh., L. argenteus Pursh, $L$. sericeus Pursh (Marsh and Clawson 1916). Many other species contain varying levels of quinolizidine alkaloids and have caused poisoning experimentally, or on isolated occasions. Most of the species that cause sheep poisoning are increaser species. They occur in the native plant communities, but increase with disturbance. In the past, the most widespread disturbance was overgrazing. Areas around watering holes, salt licks, bed grounds, and trail driveways often had dense concentrations of lupine. Lupine species also increase rapidly following fire. The combinations of dense concentrations of lupine and hungry animals that graze indiscriminately set up the conditions of poisoning. Kingsbury (1964) stated, "Almost all cases of loss occur under circumstances which cause the animals to consume large quantities of podded lupine over a brief period of time. These include driving hungry animals quickly through areas heavy with lupine, so that they have little chance to be selective in their grazing; unloading or bedding down hungry animals where lupine is the major vegetation; and trailing animals where snow has covered the grasses, leaving lupines as the only green vegetation available."

The second lupine syndrome is crooked calf disease (Shupe et al. 1967). This occurs when a pregnant cow consumes Lupine species between the 40 to $70^{\text {th }}$ days of gestation. The teratogen stops uterine motility during this period, causing permanent curvature of the spine and limbs in the position the fetus is lying. The teratogenic alkaloid anagyrine has been found in L. sulphureus, L. sericeus, L. caudatus Kell., L. laxiflorus Dougl., L. latifolius Agardh, and teratogenic piperdine alkaloids have been found in L. formosus and L. arbustus Dougl. ex Lindl.. The teratogenic alkaloids are generally higher during flowering. Keeler et al. (1977) recommended that pregnant cows should not be given access to lupine during their 40 to 70 day of gestation, especially when the teratogen level was high during flowering or in the seed pod stage.

Good range management and corresponding improved range condition has reduced dense patches of lupine, and the knowledge of the stressful conditions that cause sheep to graze it have greatly reduced the incidence of acute poisoning in sheep. Scattered incidents of crooked calf disease occur infrequently when the management recommendations of Keeler are ignored.

\section{Death Camas}

Marsh and Clawson (1922) stated that "Of all the poisonous plants which cause losses to the sheepmen of the western stock ranges, death camas (Zigadenus spp.) without a doubt, is the most troublesome." There are over 15 species of death camas distributed throughout the western states, and in many areas grow in great abundance. They contain sterodial glycoalkaloids which cause salavation, nausea and respiratory failuare. Death camas is one of the first plants to begin growth in the spring. Its early growth combined with early turnout of livestock resulted in poisoning. The range management principle to wait until range readiness when grass and other forage was available, greatly reduced poisoning problems.

Although a significant problem in the past, few cases of poisoning occur today. Dense concentrations are seldom found. Most commonly, individual plants are scattered among sagebrush and other vegetation. Furthermore, it is an apparent plant, and sheepmen know to avoid areas where it grows, especially if their sheep are hungry.

\section{Conclusion}

Western U.S. rangelands are inherently susceptible to poisonous plant problems because of the wide variety of plants containing toxic compounds. Overgrazing intensified poisoning problems by causing the desirable forage species to decline, allowing less palatable and poisonous species to increase, thereby compelling livestock to consume poisonous plants with resulting catastrophic losses. This has been a hard lesson to learn. Some ranchers are still struggling with the problem. Schuster's (1978) solution still applies, "Good range management is the surest and most economical means of reducing livestock loss to poisonous plants."

However, poisoning still occurs, even on good condition rangelands. Some poisonous plants are part of the pristine or climax plant community and will be abundant on better condition rangelands. If these species are palatable, like tall lark- 
spur, extensive management strategies must be developed to avoid the conditions where cattle are likely to eat them (Pfister et al. 1997, 1993). Abundance of other toxic plants will vary with the climate (locoweeds, milkvetch, low larkspur, lupine, snakeweed). It is necessary to recognize the weather conditions and climatic factors that favor their increase and make other grazing arrangements. In these cases, short-term herbicide control or aversion conditioning may get a rancher through the critical periods.

\section{Literature Cited}

Aldous, A.E. 1917. Eradicating tall larkspur on cattle ranges in the national forests. USDA Farmers Bull. 826.

Alley, H.P. and G. Lee. 1970. What can be done about controling larkspur on western rangelands. Down to Earth 26:31-32.

Barnes, W.C. 1913. Western grazing grounds and forest ranges. The Breeder's Gazette, Chicago. 390 pp.

Box, T.W. and J.C. Malechek. 1987. Grazing on the American rangelands. Proc. West. Sec. Anim. Sci. 38:107-115.

Chesnut, V.K. and E.V. Wilcox. 1901. The sotck-poisoning plants of Montana. USDA Bot. Bull. 26.

Dwyer, D.D. 1978. Impact of poisonous plants on western U.S. grazing systems and livestock operations. pp. 13-21, In: R.F. Keeler, K.R. VanKampen, and L.F. James (eds), Effects of Poisonous Plants on Livestock. Academic Press. N.Y.

Ellison, L. 1954. Subalpine vegetation of the Wasatch plateau, Utah. Ecol. Mono. 24:80184.

Fleming, C.E., M.R. Miller, and L.R. Vawter. 1923. The low larkspur (Delp-hinium andersoni). Univ. Nev. Agr. Exp. Sta. Bull. 105.

Looman, J. 1984. The biological flora of Canada: 5. Delphinium glaucum Watson, tall larkspur. Canada Field-Nauural. 98:345-361.

James, L.F., K.L. Bennett, K.G. Parker, R.F. Keeler, W. Binns, and B. Lindsay. 1968. Loco plant poisoning in sheep. J. Range Manage. 21:360-365.

Keeler, R.F., L.F. James, J.L. Shupe, and K.R. VanKampen. 1977. Lupine-induced crooked calf disease and a management method to reduce incidence. J. Range Manage. 30:97-102.

Kingsbury, J.M. 1964. Poisonous plants of the United States and Canada. Prentice Hall, Englewood Cliffs, N.J.

Marsh, C.D. 1909. The locoweed disease of the plains. USDA Anim. Ind. Bull. 112.

Marsh, C.D. 1913. Stock poisoning due to scarcity of food. USDA Farm. Bull. 536.

Marsh, C.D. and A.B. Clawson. 1916. Lupines as poisonous plants. USDA Bull.405.
Marsh, C.D. and A.B. Clawson. 1922. The stock poisoning death camas. USDA Farm. Bull. 1273.

MacDonald, M.A. 1952. Timber milkvetch poisoning on British Columbia ranges. J. Range Manage. 5:16-21.

Majak, W., L. Stroesser, J.H. Hall, D.A. Quinton, and H. E. Douwes. 1996. Seasonal grazing of Columbia milkvetch by cattle on rangelands in British Columbia. J. Range Manage. 49:223-227.

Nielsen, D.B. and M.H. Ralphs 1988. Larkspur: economic considerations. pp. 119129 In: L.F. James, M.H. Ralphs and D.B. Nielsen (eds), The Ecology and Economic Impact of Poisonous Plants on Livestock Production. Westview Press. Boulder Colo.

Olsen, J.D. 1978. Tall larkspur poisoning in cattle and sheep. J. Amer. Vet. Med. Assoc. 173:762-765.

Payne, G.F. 1957. Ecology and life history of the poisonous plant, white locoweed (Oxytropis sericea Nutt.). Ph.D Diss. Texas A\&M Univ., College Station, Tex.

Pfister, J.A. and D.R. Gardner. 1999. Consumption of low larkspur (Delphinium nuttallianum) by cattle. J. Range Manage. 52:378-383.

Pfister, J.A., D.R. Gardner and K.W. Price. 1997. Grazing risk on tall larkspur-infested ranges. Rangelands 19:12-15.

Pfister, J.A., M.H. Ralphs, G.D. Manners, K.E. Panter, L.F. James, B.L. Stegelmeier, and D.R. Gardner. 1993. Tall larkspur poisoning in cattle: current research and recommendations. Rangelands 15:157-160.

Quinton, D.A., W. Majak, and J.W. Hall. 1989. The effect of cattle grazing on the growth and miserotoxin content of Columbia milkvetch. J. Range Manage. 42:368-371.

Ralphs, M.H. and V.L. Bagley. 1988. Population cycles of Wahweap milkvetch on the Henry Mountains and seed reserve in the soil. Great Basin Natur. 48:541-547.

Ralphs, M.H. and E.H. Cronin. 1987. Locoweed seed in soil: density, longevity, germination and viability. Weed Sci. 35:792-795.

Ralphs, M.H., D.Graham, R.J. Molyneux, and L.F. James. 1993. Seasonal grazing of locoweeds by cattle in northeastern New Mexico. J. Range Manage. 46:416-420.

Ralphs, M.H., G.D. Manners, J.A. Pfister, D.R. Gardner, and L.F. James. 1997. Toxic alkaloid concentration in tall larkspur species in the western U.S. J. Range Manage. 50:497-502.

Schuster, J.L. 1978. Poisonous plant management problems and control measures on U.S. rangelands. pp. 23-34, In: R.F. Keeler, K.R. VanKampen, and L.F. James (eds), Effects of Poisonous Plants on Livestock. Academic Press. N.Y.

Shupe, J.L., W. Binns, L.F. James, R.F. Keeler. 1967. Llupine a cause of crooked calf disease. J. Amer. Vet. Med. Assoc. 151:198-203.

Stoddart, L.A. and A.D. Smith. 1943. Range Management $1^{\text {st }}$ Ed. McGraw-Hill, N.Y.
Stoddart, L.A. and A.D. Smith. 1955. Range Management 2nd Ed. McGraw-Hill, N.Y.

Stoddard, L.A., A.H. Holmgren, and C.W. Cook. 1949. Important poisonous plants of Utah. Utah Agr. Exp. Sta. Special Report 2.

Stoddart, L.A., A.D. Smith and T.W. Box. 1975. Range Management 3rd Ed. McGrawHill, N.Y.

Valentine, J.F. 1990. Grazing Management. Academic Press, N.Y.

Welsh, S.L. 1989. Astragalus L. and Oxytropis DC.: definitions, distributions, and ecological parameters. pp. 3-13, In: L.F. James, A.D. Elbein, R.J. Molyneux, C.D. Warren (eds.), Swainsonine and Related Glycosidase Inhibitors. Iowa State Univ. Press. Ames Iowa..

Wilcox, E.V. 1897. Larkspur poisoning of sheep. Mont. Agr. Exp. Sta. Bull. 22.

Williams, M.C., L.F. James and B.O. Bond. 1979. Emory milkvetch (Astragalus emoryanus) poisoning in chicks, sheep and cattle. Amer. J. Vet. Res. 40:403-406. 